\title{
From Healing to Protective Disaster Coping Efforts: An Evaluation of Building Inspection Approaches within the Disaster Policies Developed between 1924 and 2010 in Turkey
}

\author{
Ali Tolga Ozden ${ }^{1, *}$, Mualla B. Erkilic ${ }^{2}$ \\ ${ }^{1}$ Department of Architecture, Faculty of Architecture, Süleyman Demirel University, Turkey \\ ${ }^{2}$ Department of Architecture, Faculty of Architecture, Middle East Technical University, Turkey
}

Copyright $(\mathcal{C} 2015$ by authors, all rights reserved. Authors agree that this article remains permanently open access under the terms of the Creative Commons Attribution License 4.0 International License.

\begin{abstract}
Turkey has long been suffered due to destructive impacts of earthquakes and has tried to develop pre and post disaster coping efforts by means of laws and policies since 1924. During this period, along with the developing national and international policy changes, a shift has occurred from traditional post-disaster (healing) to pre-disaster (protective) efforts in terms of disaster mitigation. During a brief historical evaluation of administrative advancements in terms of shifting understanding of disaster in Turkey a focus is given to development of ideas related to building inspection which was formally initiated as a risk-reduction approach after 1999. Knowledge gathered from interviews conducted among administrative and building professionals between 2008 and 2012 contribute to the critical evaluation of the administrative problems of the Building Inspection System (BIS) carried out today. It is revealed from this research that there is an urgent need for unifying the scattered and complex forms of legislations related to disaster issues in Turkey. It is revealed also that a risk-reduction approach has not been conducted in consistent with the practice of BIS in which the enforcement of the necessary knowledge and ordinances remain insufficient among its participants: building professionals, inspector firms and local authority. It is underlined, also that the legal and administrative advancements are not enough to achieve disaster resilient society if they are not digested by the community from a holistic perspective of disaster perception in the country.
\end{abstract}

Keywords Earthquake, Disaster, Coping Policy, Building Inspection System, Risk-reduction

\section{Introduction}

In Turkey earthquake is the most destructive natural disaster among the others including those of flood, landslide, fire, avalanche. The recent statistics show that there is a considerable number of people who continuously face with the destructive impacts of earthquake hazards in the country [1-6]. The inadequacy of the disaster coping efforts increases this destructive impacts further. The legal and administrative advancements that took place in the period between 1924 and 2010 can be analyzed in two main periods: The period between 1924-1999 and the period between 1999-2010. The administrative policies and organizations developed in the first period indicate that until 1999, earthquake disaster coping efforts have mostly depended on post-disaster rehabilitative programs -with a little attention given to pre-disaster (or protective) efforts- that have been initiated, usually, following severe seismic events occurred in different parts of Turkey. Besides having some piecemeal and incremental shifts towards mitigation approach, an important shift in disaster coping effort - from rehabilitative to protective one - took place after the very dramatic experience of 1999 Marmara earthquake. Building Inspection System (BIS) was initiated for the first time in a formal way with a support of the Building Inspection Law, at this period as a risk-reduction approach developed for building professionals to control and prevent the damages caused by built environment during disasters. This paper aims to explore briefly the legal and administrative approaches in relation to seismic events which organize and control building practices in a historical perspective and to evaluate critically the application system of BIS in order to highlight the ongoing administrative problems.

The period between 1924-1999: After the foundation of Republic in Turkey in 1923 the first law entitled Village Law (n: 442) was enacted in 1924. The article 13 in this Law, 
considered the precautions that should be taken before the natural hazards [7]. In the same year, following the intensive earthquake of Erzurum province, the Law 516 was enacted to cover the aids and rehabilitation programs during disaster events [8-9]. The Municipality Law (n: 1580) was put into effect in 1930 which involved issues related to inspection activities and disaster preparedness. The article 15, in this Law, pointed out simply the construction and material inspection responsibility of municipalities [10]. During this period between 1930 and 1944 various institutions were established and several laws enacted that indirectly referred to the legal and administrative arrangements in coping with disasters. In 1939 following the destructive seismic event Erzincan the Post-Disaster Assistance Law (n: 3773) was put into effect. That law was a case specific legislative arrangement and it covered, merely, post disaster rehabilitative and aid activities [11].

Following a series of earthquakes recorded between 1939 and 1944, it was understood clearly that post-disaster activities such as first aid and rehabilitation were not sufficient in order to develop successful and integrated coping strategies for disasters $[8,12]$. It was also realized to develop better policies and legislative approaches in order to improve the resistance of the built environment against disasters. Considering this issue The Law for The Measures That Would be Taken Before and After The Earthquakes was (n: 4623) eanacted in 1944. This Law included the identification of seismic hazard zones of Turkey, determination of the constructional building codes for earthquake resistant buildings, preparations for emergency operation, programs for safety assessment after disasters, arrangement of relocation of settlements, geographical surveys for safe developmental areas, and regulation of financial issues [12-13]. This Law can be accepted as an important step in the establishment of a legislative and administrative guideline for building professionals, municipalities, public, and other related institutions who aim to produce safe environment for people. However, the Law predominantly consisted of post-disaster or rehabilitation activity arrangements through its articles in terms of first-aid, temporary sheltering, repairment, reconstruction and/or demolishing of damaged buildings in the disaster stricken areas.

In 1945, besides the production of the Earthquake Zones Map of Turkey, the Earthquake Zones Building Regulation of Turkey was developed to give information about the regulations concerning the structural character of earthquake resistant buildings [14]. This regulation has revised (in 1996, 1997, and 2007), and is still in use under the title of Regulation for the Buildings that will be constructed in the Disaster Zones [15]. In 1948 the Law entitled The Buildings that would be Constructed in Erzincan (n: 5243) was enacted which covered the arrangement of post-disaster and case specific disaster problems of reconstruction activities following the Erzincan earthquake [16]. Establishment of Earthquake-Flood-Fire Office in 1955 [17, 18] was important because it aimed to combine the coping efforts with three major hazards contributed to the shifting understanding of disaster coping strategies from a more integrated point of view.

The period between 1956 and 1960 was successful in terms of advancements in legal and administrative systems related to improving disaster coping efferts. The Development Law (n: 6785) enacted in 1956 covered technical application resposibility system for building inspection aiming to take necessary measures before disasters to improve the quality standards of housing and settlement [19]. Further in 1959 The Law for Arranging Measures Taken Before and Assistance after the Disasters that are Effective on to the Public Life (n: 7269) [20]was enacted and it combined all the previous laws and policies related to disaster issues in its body [17]. All these advancements reveal that there has been a shift in understanding of disaster cooping efforts from healer to protector. This is significant for the development of built environment and its inspection during pre-disaster period.

However, the destructive effect of the seismic activities between the years 1966 and 1983 (in Varto 1966, Gediz 1970, Bingol 1971, Lice 1975, Muradiye 1976, Erzurum-Kars 1983 provinces) had revealed that the previous successful developments through the legal and administrative structures did not effectively reflect into the practice due to insufficient application and administration process. This situation revealed also that pre disaster programs such as building inspection was in need of urgent developments. In order to improve building production process, as well as inspection activities, a new Ministry of Public Works and Settlement was established in 1983 [21].

The legal and administrative developments that took place between 1985 and 1999 revealed that the laws and the law based regulations were mostly case specific solutions and they represented a dualistic character while considering traditional disaster coping effort (healing) and pre-disaster protector efforts separately. For example, The Development Law (1985) (n: 3194) [22] concentrated on guiding principles of building codes for inspection of buildings whereas The Regulation of Disaster Related Emergency Assistance Organization and Planning Fundementals; (n: 88/12777) (1988) concentrated on the post disaster aids and organisations. Similarly different case specific efforts were put into effect following the severe impacts of earthquakes in different part of Anatolia between 1992 and 1995. It was in 1996 more comprehensive regulation entitled The Regulation for the Buildings That Will be Constructed in the Disaster Prone Areas targeting to enhance the mitigation activities was initiated [23]. This regulation aimed to guide building professionals and related institutions participating in building production process in disaster prone areas. This regulation covered also the destructive results of fire and flood in an integrated way. However, in 1997, the focus was shifted to the post disaster approach and ThePrime Ministry Crisis Management Center (96/716) [24] was established for rehabilitation activities.

The period between 1999 and 2010: The year of 1999 
has never been forgotten in terms of heavy impacts of a

November 1999, two very powerful earthquake shaked western Turkey, the Marmara region with a magnitudes of 7.6 and 7.2. A new legal and administrative structuring was demanded to cope with post-disaster issues and to enhance the mitigation policies. A Decree Law (n: 4452) which gives all authorization to the government to develop all legislative and administartive issues was established in a short period [8, 17]. The aim of that authorization law was defined as the development of necessary laws and regulations regulating post-disaster aids, financial aids, resettlement development, construction, contracting, protection of cultural and natural assets, civil defence, development of new funds, development of a natural disaster insurance system etc. [25]. It must be noted that within two years series of decree laws were established to support the above mentioned law. For example, a new administrative institution entitled Turkey Emergency Management Presidency was established in 2000 by a Decree Law 583 and converted to General Directorate in the year 2000 by the Decree Law of 600 [8]. Mandatory Earthquake Insurance was establishedin 1999 within a Decree Law (n: 587) to support mitigation activities.

One of the most important Decree Laws related to the re-organization of building inspection regulations which was by a new law Building Inspection Law (n: 4708) in 2001. According to this law a remarkable shift in building production process occurred. It was aimed to enhance and develop more effective inspection activities by means of Private Building Inspection Firms. The ongoing Building Inspection System (BIS) as an important mitigation effort which has been in effect by the application of Building Inspection Law has developed in accordance with the shifting disaster coping policies of the international agenda and triggering effects of 1999 earthquakes. The former inspection system was determined as an ill-structured and deficient model that caused failure and corruption in building production process in Turkey [26-27]. In addition, the major three international disasters policy shift that effects the developments in Turkey following the devastating 1999 earthquakes can be given as follows [28]:

- United Nations' (UN) decision of programming the years 1990-2000 as the IDNDR (International Decade for Natural Disaster Reduction),

- International Organization of Yokohama Conference in 1994 in which the new strategies and principles of coping policies with natural disasters were developed, natural disaster in Turkey's disaster history. In August and

- Development of ISDR (International Strategy for Disaster Reduction) in 2000 as a new branch of UN.

The inspection system as an important risk reduction attempt aims to supervise and control building professionals' performance in order to promote disaster resistant buildings through the Building Inspection Law. The purpose of the new inspection approach is defined as the arrangement of the life and asset safety by the supervision of design and building in order to achieve quality in construction which obeys the rules of related building plan, science - art and health standards [29].

Although there had been several attempts to infuse pre-disaster and risk reduction approach into the legal and administrative achievements particularly since 1960s as outlined above, the establishment of BIS in 2001 shows that the shift in legal and administrative risk reduction approach to the disaster phenomenon became more apparent and structured in technical sense. This establishment is important also because built environment is the foremost problematic area that creates high risk in human life during disaster events and needs to be well ordered in terms of technical construction and administration. In this paper we try to evaluate the administrative processing system of BIS and point out the problems and conflicts that occur during its application among its participants. It must be noted that the contextual parameters of BIS such as codes of technical system and materials are equally important in the processing of BIS and are in need of crital evaluation among building professionals. However, this evaluation remains out of the scope of this paper. The interview among building professionals and administrators of BIS give important clues about the administrative problems of the processing of BIS.

The interviews are conducted (within a research carried out between 2007-2012) among nine professionals between 2008 and 2012 and interviewees are the randomly selected working participant of Building Inspection Firms, The Presidency of Building Inspection Commission under the Ministry of Environment and Urbanization, Continuing Professional Development Center, Chamber of Architects of Turkey, Union of Municipalities of Turkey, General Directorate of Provincial Bank, and the Greater Municipality of Ankara. A qualitative research methodology comprising the in-depth interviews is used in order to collect the necessary data. The interviews given below briefly focus on building professionals' ideas concerning the administrative and application structure of BIS. 


\begin{tabular}{|c|c|c|c|c|c|}
\hline \multicolumn{6}{|c|}{ Interviewee 1: Inspector architect (vice president of Union of Building Inspection Firms) } \\
\hline organizational structure & \multicolumn{3}{|c|}{\begin{tabular}{l|l} 
implementation of the BIS & \\
\end{tabular}} & \multicolumn{2}{|r|}{ competency of professional } \\
\hline $\begin{array}{l}\text { 1. Inharmonious with the ongoing } \\
\text { traditional contractor system, } \\
\text { 2. Deficient organization of financial } \\
\text { system that cause corruptive interactions } \\
\text { between contractors and inspectors. }\end{array}$ & \multicolumn{3}{|c|}{$\begin{array}{l}\text { 1. Exemption of public buildings from the BIS } \\
\text { cause equality problems among the buildings, } \\
\text { 2. Exemption creates series of administrative } \\
\text { problems due to its unclear and unfair approach. }\end{array}$} & \multicolumn{2}{|r|}{$\begin{array}{l}\text { 1. Ineffective legal system that does not enforce } \\
\text { and/or facilitate compulsory professional training } \\
\text { system, } \\
\text { 2. Unclear and/or undefined responsibility } \\
\text { definitions of the building professionals within the } \\
\text { inspection system legislation. }\end{array}$} \\
\hline \multicolumn{6}{|c|}{ Interviewee 2 and 3:City Planner and Civil Engineer (Presidency of BIS commission) } \\
\hline responsibilities of inspection firms & \multicolumn{4}{|c|}{ responsibilities of building professionals } & competency of \\
\hline $\begin{array}{l}\text { 1. Due to the insufficient legislative } \\
\text { formation and the lack of necessary } \\
\text { professional competency, contrary to the } \\
\text { expectations, the inspection firms remain } \\
\text { least active partition within BIS. }\end{array}$ & \multicolumn{4}{|c|}{$\begin{array}{l}\text { 1. Doubt and obscurity on responsibilities and } \\
\text { rights of building professionals that make them not } \\
\text { to share responsibilities accurately with other } \\
\text { participants in the implementation process of BIS, }\end{array}$} & $\begin{array}{l}\text { 1. Urgent need to train professional inspectors } \\
\text { as the expertise of the inspection of different } \\
\text { types of buildings (industrial, buildings, } \\
\text { housing etc.). }\end{array}$ \\
\hline \multicolumn{6}{|c|}{ Interviewee 4:Architect (Continuing Professional Development Center) } \\
\hline \multicolumn{6}{|c|}{ competency of professionals } \\
\hline \multicolumn{6}{|c|}{$\begin{array}{l}\text { Although the continuing professional development system and its relation to training of building professionals who are serving in BIS are very } \\
\text { important; } \\
\begin{array}{l}\text { 1. Insufficient training model which needs more detailed training programs including legal and administrative process of BIS in addition to regular } \\
\text { continuing professional training services, }\end{array} \\
\text { 2. Ineffective use of developing training technologies causes participation problems and knowledge access among building professionals. }\end{array}$} \\
\hline \multicolumn{6}{|c|}{ Interviewee 5:Architect (Professional inspector in a private inspection firm) } \\
\hline \multirow{2}{*}{\multicolumn{2}{|c|}{$\begin{array}{l}\text { responsibilities and rights of building professionals } \\
\begin{array}{l}\text { Oomplicated and obscuring responsibility sharing among } \\
\text { sional participants in BIS due to the lack of administrative } \\
\text { clarities on this subject, }\end{array} \\
\end{array}$}} & \multicolumn{4}{|c|}{ competency and professional training } \\
\hline & & & $\begin{array}{r}\text { 1. Insuffici } \\
\text { Dialogical problem be } \\
\text { institutions due to }\end{array}$ & & $\begin{array}{l}\text { n projectitation model of certifying, } \\
\text { nsufficient capacity of the professionals, }\end{array}$ \\
\hline \multicolumn{6}{|c|}{ Interviewee 6:City Planner (General Directorate of Provincial Bank } \\
\hline organizational structure & \multicolumn{3}{|c|}{ implementation of the BIS } & & competenc \\
\hline $\begin{array}{l}\text { 1. Limitation of the BIS to } 19 \text { provinces } \\
\text { whereas the other } 63 \text { provinces were } \\
\text { exempted from the system in the period } \\
\text { between } 2001-2012 \text {, } \\
\text { 3.Exemption building approach creates series } \\
\text { of administrative problems due to its unclear } \\
\text { and ill-structured approach. }\end{array}$ & \multicolumn{3}{|c|}{$\begin{array}{l}\text { 1. Inharmonious and fragmented } \\
\text { implementation and legal system, } \\
\text { 2. Misunderstanding and deficient } \\
\text { applications among the building } \\
\text { professionals due to fragmented system, }\end{array}$} & & $\begin{array}{l}\text { 1. Insufficient training system and deficient } \\
\text { npetency among the inspectors result in failure } \\
\text { through the building inspection process, } \\
\text { Insufficient awareness and lack of necessary } \\
\text { acity in inspection process among the building } \\
\text { owners. }\end{array}$ \\
\hline \multicolumn{6}{|c|}{ Interviewee 7:Vice Secretary General (Union of Municipalities of Turkey) } \\
\hline \multicolumn{3}{|c|}{ organizational structure } & \multicolumn{3}{|c|}{ implementation of the BIS } \\
\hline \multicolumn{3}{|c|}{$\begin{array}{l}\text { 1. Coordination problems between institutions, } \\
\text { 2. Insufficient approaches of the all BIS actors in terms of arranging a } \\
\text { well-functioning system among the legal and the administrative } \\
\text { structure. } \\
\begin{array}{c}\text { 3. Gaps in implementation process due to deficient coordination } \\
\text { between stakeholders of the BIS. }\end{array} \\
\end{array}$} & \multicolumn{3}{|c|}{$\begin{array}{l}\text { 1. Ineffective inspection efforts of the municipal organizations due to lack } \\
\text { of necessary technical sources and competent professionals, } \\
\text { 2. Failure of inspection responsibility of the municipalities in terms of } \\
\text { inspecting the inspection firms' works. }\end{array}$} \\
\hline \multicolumn{6}{|c|}{ Interviewee 8:City Planner (Greater Municipality of Ankara) } \\
\hline \multicolumn{3}{|c|}{ implementation of the BIS } & \multicolumn{3}{|c|}{ competency and professional training } \\
\hline \multicolumn{3}{|c|}{$\begin{array}{l}\text { 1. Lack of reliable soil survey and related information in order to } \\
\text { develop hazard maps which affect the success of the application efforts } \\
\text { and cause failure in the occupancy period of buildings when they face } \\
\text { with hazardous events. }\end{array}$} & \multicolumn{3}{|c|}{$\begin{array}{l}\text { 1. Insufficient capacity of the professionals in the inspection firms and the } \\
\text { municipalities which does not meet to achieve reliable inspection } \\
\text { practices, } \\
\text { 2. Lack of competency of building inspection professionals due to } \\
\text { inadequate professional training and accreditation system. }\end{array}$} \\
\hline \multicolumn{6}{|c|}{ Interviewee 9:Geological Engineer (Director of the Disaster Coordination Department, Greater Municipality of Ankara) } \\
\hline organizational structure & impleme & & 1 of the BIS & & competency and professional training \\
\hline $\begin{array}{l}\text { 1. Defective inspection activities of local } \\
\text { municipal organizations due to their } \\
\text { political formation and economic relations } \\
\text { within the free market system, } \\
\text { 2. Corruption and unethical behavior of } \\
\text { municipal professionals that forms barriers } \\
\text { for inspection activities. }\end{array}$ & $\begin{array}{r}\text { 1. Failure in reliab } \\
\text { to ill-structured fin } \\
\text { and organize } \\
\text { 2. Lack of reliabl } \\
\text { maps that reveal th } \\
\text { affect to achie } \\
\text { inspe }\end{array}$ & & $\begin{array}{l}\text { Dection activities due } \\
\text { system that regulate } \\
\text { pection activity, } \\
\text { guiding soil survey } \\
\text { and conditions which } \\
\text { effective and safe } \\
\text { activity. }\end{array}$ & & $\begin{array}{l}\text { 1. Inadequacy of competent building } \\
\text { professionals participating to the inspection } \\
\text { activities within the inspection firms, } \\
\text { 2. Unawareness among the professionals about } \\
\text { mportant progressing information related to the } \\
\text { ffective inspection system due to technical and } \\
\text { legal innovations. }\end{array}$ \\
\hline
\end{tabular}




\section{Conclusions}

Disaster coping struggles have been changed in decades due to scientific, technical, and organisational advancements. BIS can be considered as the foremost advancements among the disaster coping policies that shift from traditional rehabilitative to risk-reduction approach in Turkey. However, this system has still gaps and deficiencies in terms of legislative and administrative structures in practical implementation process. These deficiencies varies from the insuffiency and complexity of implementation and apadtation of new regulations to traditional building production system to the responsibilities, rights, and competency - training of building professionals, inspection firms and members of local authority. This complexity relates to the complexity of current legislative documents that often overlap and have contradictions related to disaster issues. A more comprehensive and unifying legislation may help the development of a holistic, integrated protective risk reduction approach in disaster coping efforts in the country.

\section{REFERENCES}

[1] TCIP, 2011. Turkish Catastrophe Insurance Pool statistics. http://www.tcip.gov.tr/100.html

[2] AFAD, 2011. Natural Disaster Risk for Provinces of Turkey. Prime Ministry Disaster and Emergency Management Presidency. http://www.afetacil.gov.tr/index.html

[3] EM-DAT, 2011. Country Profile: Turkey, The International Disaster Database, Centre for Research on the Epidemiology of Disasters - CRED. http://www.emdat.be/country-profile

[4] Ergünay, O., 2007. Disaster Profile of Turkey, TMMOB Disaster Symposium, Ankara.

[5] Yazıc1, S., 2007. Turkish Catastrophe Insurance Pool and Mandatory Earthquake Insurance, Comprehensive Natural Disaster Risk Management Program, World Bank Institute Distance Learning, METU, October 22-December 2, Ankara.

[6] Genç, F. N., 2007. Natural Disasters in Turkey and Risk Management in Natural Disasters, Stratejik Araştırmalar, 9(9): 201-225.

[7] Official Gazette, 1924a. n.68: 336, April, 7.

[8] Ergünay, O., 2011. How the 1999 Earthquakes Changed the Disaster Legislation: Where We are in Terms of Legislation, 1st Earthquake Engineering and Seismology Conference of Turkey, 11-14 October, METU, Ankara.

[9] Official Gazette, 1924b. n.79: 1, November, 24.

[10] Official Gazette, 1930. n.1471: 8821-8839, April, 14.

[11] Official Gazette, 1940. n.4416: 13205-13212, January, 25.

[12] TBMM, 1997. Report of the Research Commission of the Turkish Parliament, The Grand National Assembly of Turkey, No: 01.1.GEÇ.10/58-72:345, June 20.

[13] Official Gazette, 1944. 5763: 7337-7348, July, 22.

[14] Öztürk, N., 2003. Disaster Management in Turkey: Problems Encountered and the Suggestions for Solutions, Çağdaş Yerel Yönetimler, 12(4): 42-64.

[15] Official Gazette, 2007a and b. n.26582, July, 14 and n.26454, March, 6.

[16] Official Gazette, 1948. n.6955: 14369-14383, July, 12.

[17] Erkan, E.A., 2010. Risk Reduction in Disaster Management and the Problems in Turkey, Specialist Thesis, No: 2812, State Planning Organization, Ankara, Turkey.

[18] Sipahioğlu, S. and Alptekin, Ö.,1988. Present Appearence of Earthquake Problem in Turkey, Jeofizik Journal, 2: 151-183.

[19] Official Gazette, 1956. n.9359: 15109-15124, July, 16.

[20] Official Gazette, 1959. n.10213: 21695-21714, May, 25.

[21] Official Gazette, 1983. n.18251: 1-432, December, 14.

[22] Official Gazette, 1985. n.18749: 1-64, May, 9.

[23] Official Gazette, 1996. n.22635: 1-320, May, 13.

[24] Official Gazette, 1997. n.22872: 1-96, January, 9.

[25] Official Gazette, 1999. n.23801: 1-96, August, 29.

[26] Özkan, G., 2005. Building Inspection Related Approaches in Turkey, Unpublished Master Thesis, Y1ldız Technical University, İstanbul.

[27] Y1lmaz, H., 2006. Tendency to Transfer of Urban Planning Services to the Private Sector After 1980 in Turkey: Building Inspection Firms Example, Unpublished PhD Thesis, Ankara University, Ankara

[28] Balamir, M., 2011. Major Axis of the International Disasters Policy: Urban Mitigation, 1st Earthquake Engineering and Seismology Conference of Turkey, 11-14 October, METU, Ankara.

[29] Official Gazette, 2001. n.24461: 1, July, 13. 